\title{
Socio-cultural and institutional factors of the investment potential of the regions of the Russian Federation
}

\author{
Natalia Filatova*, Nikolay Zaikin, Yuri Kazantsev \\ Department of Economics and Investments, Siberian Institute of Management - branch of Russian Presidential \\ Academy of National Economy and Public Administration (Siberian Institute of Management, Branch of \\ RANEPA), 630102, Novosibirsk, 6 Nizhegorodskaya Str., Russia
}

\begin{abstract}
The article discusses the problem of sustainable development of the regional economy considering the consequences of the 2020 pandemic. The authors make an assumption about the stabilizing effect of the previously accumulated investment potential at the regional level. Regions with high investment potential have a high degree of the regional economy resilience. The object of the study was the dynamics of socioeconomic indicators of investment potential in 85 constituent entities of the Russian Federation for the period from 2009 to 2018. To consider the long-term development trend of the region, institutional and sociocultural variables were added to the system of indicators of the regression model. The results of the regression analysis indicate the importance of only one of the tested institutional and social factors - the volume of issued housing mortgage loans. The affordability of housing for the region population can be an important factor in the sustainability of the regional economy and be considered as a key benchmark of the regional investment strategy.
\end{abstract}

\section{Problems}

The consequences of restrictive measures within the 2020 pandemic, as well as their decentralized nature at the regional level, led to increase in differentiation of regions in terms of the level of socio-economic development. Scientists' estimates showed that economic activity in the country after introduction of restrictions decreased by almost a quarter, spatial differences between regions increased, while the most developed regions suffered the most [3].

Researchers note a different degree of stability (resilience) of the region's economy development that is understood as resistance to the impact of Russian regions to external shocks [5] [14]. The stability to external and internal shocks is understood as the ability to recover and preservation of the pre-crisis development trend. Scientists note that the scale of the regional economy is not the main factor in the sustainability of the region and highlight the importance of regional components of economic policy: pre-crisis dynamics

${ }^{*}$ Corresponding author: filatova-ng@ranepa.ru 
of socio-economic indicators of the region, market size, investment growth rates. Regions with a diversified economic structure have a high adaptive potential (resistance to external shocks), a high contribution to which is made by large urban agglomerations.

A number of scientists are analyzing the impact of the 2020 pandemic on changes in the income and expenditures of the consolidated budgets of the constituent entities of the Russian Federation, as well as the level of their debt [2]. The authors identify transfers from the federal budget as the main factor of resistance to shocks in regional budgets. Wherein, there is a high differentiation of incomes of the budgets of the regions of the Russian Federation. The greatest blow to regional budgets was made by decline in tax revenues from the mineral extraction tax. In this regard, the economic consequences of the pandemic were most acutely felt by the resource-extracting regions of the Ural, Siberian and Northwestern Federal Districts [4].

Special attention shall be paid to the papers of domestic authors who study the sectoral effects of the pandemic in the regional economy [1]. The studies note a decline in investment in most regions of the Russian Federation and an emerging trend towards concentration of investment in regions with maximum competitive advantages - in large regional centers and in regions dominated by industries with a high rate of return on capital (oil and gas producing regions). For the regions of the Ural Federal District, investments acted as a smoothing factor in decline in tax revenues of the regional budget.

Therefore, the dynamics of regional development within pandemic confirms the hypothesis about the stimulating effect of investments. Investment activity continued in regions with a diversified economic structure and in a number of oil and gas producing regions. According to the national rating of the investment climate in the constituent entities of the Russian Federation for 2020, positive dynamics were demonstrated by the Moscow Region, Krasnodar Territory, the Republic of Bashkortostan, Yaroslavl Region, Novgorod Region, Khanty-Mansi Autonomous Okrug'1.

The investment attractiveness of territories can vary over the time interval and depend on many factors. In modern conditions, the regions are also able to compete with each other for attracting investments via formation of a regional financial system to support investors and development as a condition for economic growth, but also as a factor in the regional economy resilience. In order to systematically study the factors of sustainable development of the regional economy, the institutional environment. Wherein, the high investment potential of the region can serve not only with a prolonged effect, there is a need for a more detailed study of the factors of investment potential: economic, institutional, and sociocultural ones.

\section{Investment Potential Factors: Methodology Overview}

A review of scientific publications devoted to the issues of stimulating and attracting investments at the level of individual territories, gives a broad understanding of the methods and factors that underlie the modern methodology for analyzing investment potential.

First of all, let's consider the long-term factors of development.

Studies of Indian scientists conducted over 20 years (1996-2017) on empirical data of 3.5 thousand enterprises demonstrate a positive relationship between intangible assets and profitability of enterprises in a particular industry. Scientists offer to introduce a new indicator "industry institutional index" [10]. In their view, institutional forces within

\footnotetext{
${ }^{1}$ https://asi.ru/government_officials/rating/
} 
industries influence strategic variables at the firm level, namely, internalization, size of intangible assets, and affiliation with a business group.

In the studies of scientists from the UK, an analysis of the institutional project as a form of existence of a hybrid organization was carried out. On the example of implementation of the defense procurement project that started in the early 80 s of XX century revealed various stages of the project from distrust to formation of actually long-term alliances [22]. The theory and practice of this study are important, since they reflect the processes that attract both public and private organizations to solve socially important tasks associated with implementation of long-term investment projects. Note that the most vividly formal institutions manifest themselves in such an area of social reproduction as a green economy, namely, renewable energy [18].

Let's note an impressive set of mathematical and statistical techniques and methods used to assess the institutional factors of investment potential. So, to assess the degree of centralization of financial institutions in order to effectively manage investment risks, a synthetic method based on the Clayton copula (D. J. Clayton) and planar graphs (the planar maximally filtered graph method) is used [21].

Impact of institutional factors on development of the business environment attracts the attention of scientists from different countries. The studies highly assess the role of crosscultural exchange in the innovative development of Asian firms operating in Western markets, namely, the positive impact of formal institutional differences between Eastern and Western partners on the ability of the former to accelerate their own innovation processes has been revealed; to prove hypotheses, the authors used the hierarchical regression analysis; the assessment parameters represented the perception of such indicators as innovation, crosscultural business networks, formal and informal institutional distances, and etc. [20].

The positive effect of external (in a specific case - foreign) investment is evidenced by a study of development of the export policy of firms in some cities of the PRC [12]; monitoring indicators, among other things, were the indicators of the openness of the region's economy, the export balance, the size and age of the company, the shares of public and private participation in the equity capital, the level of education of top management, and etc. Among the conclusions, it is noted that state control and state financing contribute to the growth of the competitiveness of the enterprise and its products to a lesser extent in comparison with the results of private investment initiatives.

However, state participation in stimulating entrepreneurial activity is undeniable. Based on data from the United Nations, the World Bank, the Organization for Economic Cooperation and Development and several other international organizations for 13 years starting in 2006, our Portuguese colleagues have shown a direct the influence of formal institutions on entrepreneurial, innovative and competitive activity in the complex; researchers applied multiple regression for unbalanced panel data; the following indicators are used as criteria: the number of newly opened business entities per 1,000 people of the population (New business density), Total Early Stage Entrepreneurial Activity [19].

For its part, Western markets can be attractive for investors from developing countries that is proved by the example of the behavior of entrepreneurs from African countries: desperate to overcome the weakness of the formal institutions of the national economy, they form generally successful business communities in Great Britain [16]. Researchers have obtained similar results using the example of Turkey: based on data for 2002-2016. The Central Bank of the Republic of Turkey and a number of other national organizations determined the priority for the export of capital by Turkish companies to countries with more developed institutions [13].

This kind of research casts doubt on stimulation of the socio-economic development of poor countries and regions in favor of investment in the economy of rich countries. For example, the study of socio-economic reforms in Kenya focuses on institutional conflicts 
that impede or hinder the stimulating activities of the authorities [7], which can be considered as indirect confirmation of the relative unattractiveness of developing territories for investment purposes.

However, the study of colleagues from the PRC reveals a certain relationship between development of formal institutions and the investment activity of firms: the study of the experience of newly created enterprises for a period of more than 7 years starting from 2009 suggests that the willingness to attract foreign direct investment in an institutionally underdeveloped environment is all the higher, the more the firm is cost-effective [9]. Another study of the innovative activity of Chinese companies revealed increased requirements for the institutional environment at the municipal level as a driver of innovation and investment [17].

The governments of the Balkan countries (Serbia, Montenegro, Bosnia and Herzegovina, North Macedonia and Albania) followed the path of reforms in order to improve the economic situation, which became the subjects of research of colleagues from Serbia; the econometric model included significant institutional definitions such as corruption, political stability, transparency and public responsibility of the authorities, the rule of law and security, and others; as a result, an undeniable relationship emerged between the success of institutional changes and economic growth [15].

The Balkan countries are striving to join the European Union, so it is permissible to believe that governments are purposefully building formal free market institutions. On the example of the economic behavior of the indigenous peoples of Mexico, the significance of traditional institutional ties is revealed - in intra-tribal relations [11]. Complexly arranged tribes adapted better to economic changes (namely, to distribution of land holdings) than their politically weakly determined neighbors.

Natural resources are generally a problem in formation of market institutions. After examining data for 91 countries for 1973-2005, European scientists came to the confirmation of the "first law of petropolitics" (The First Law of Petropolitics, T. L. Friedman) [8]: in fact, this means that civil society institutions influence economic development to a greater extent than financial institutions.

Therefore, modern scientists, along with economic, financial, social and infrastructural factors of investment potential, highlight the increasing role of institutional and sociocultural factors in development of territories. Inclusion of institutional and socio-cultural determinants in the system of indicators for assessing investment potential will allow to consider the long-term development trend of territories and the nature of the resilience of the regional economy.

\section{Model Description}

The study database was built on the basis of open sources: regional statistics of Rosstat, data from the Ministry of Economic Development of the Russian Federation, the Central Bank of the Russian Federation.

The purpose of this study was to determine the determinants of investment potential in the long term, therefore, all indicators reflect a 10 -year trend.

The estimated base includes 850 observations over 85 Russian regions for the period from 2009 to 2018. Data for the Republic of Crimea and the city of Sevastopol are available only since 2014, for the rest of the regions - since 2009.

The study of the references made it possible to form a list of indicators of investment potential, including by combining them into groups. Five groups of indicators were identified, including: social, financial and economic, sociocultural, institutional, infrastructural ones (Table 1). 
The complexity of the analysis lies in the small set of institutional indicators and lack of socio-cultural indicators assessed by Russian statistics. In fact, only some indicators of the number of institutions and organizations of financial and other institutions are available to researchers. In this regard, socio-cultural and some institutional (volume of innovative goods) indicators are the resultant sociocultural and institutional factors.

Therefore, the indicator of the volume of innovative goods reflects the quality of intellectual property institutions, the number of cars and the birth rate of organizations - the cultural characteristic of individualism, the volume of mortgage loans and the birth rate the cultural characteristic of long-term orientation.

Table 1. Explanatory variables of the regression model.

\begin{tabular}{|c|c|c|}
\hline Variable group & Variable & Value \\
\hline \multirow[t]{3}{*}{ Social } & Average annual population & Population \\
\hline & Work force & Chislecon \\
\hline & $\begin{array}{l}\text { Actual final household consumption per } \\
\text { capita }\end{array}$ & Potreb \\
\hline \multirow{13}{*}{$\begin{array}{l}\text { Financial and } \\
\text { economic }\end{array}$} & Gross regional product per capita & GRP \\
\hline & Average per capita cash income & AvIncomes \\
\hline & Balanced financial result of enterprises & Saldofin \\
\hline & Mining & Dobycha \\
\hline & Manufacturing output & Vobrab \\
\hline & Retail trade turnover per capita & Torgobotot \\
\hline & Export volume of products & Vexp \\
\hline & Import volume of products & Vim \\
\hline & $\begin{array}{l}\text { The amount of works performed by } \\
\text { "construction" type of activity }\end{array}$ & Build \\
\hline & Agricultural products & $\mathrm{sel} / \mathrm{hoz}$ \\
\hline & Fixed assets cost & BAssets \\
\hline & Consolidated budget expenditures & consbudzh \\
\hline & Freight turnover of road transport & Frturnover \\
\hline \multirow[t]{4}{*}{ Sociocultural } & $\begin{array}{c}\text { Birth rate of organizations per } 1,000 \\
\text { organizations }\end{array}$ & $\mathrm{DO}$ \\
\hline & Birth rate & Fer \\
\hline & Volume of residential mortgage loans & Mortgage \\
\hline & $\begin{array}{l}\text { Provision of the population with cars (per } \\
1,000 \text { persons from the population) }\end{array}$ & Auto \\
\hline \multirow[t]{3}{*}{ Institutional } & Presence of special economic zones ${ }^{2}$ & OEZ \\
\hline & Volume of innovative products & innov \\
\hline & Number of regional banks & Banksreg \\
\hline Infrastructure & Density of highways & Roads \\
\hline
\end{tabular}

${ }^{2}$ Dummy variable, where value 1 corresponds to the presence of a special economic zone in the region, 0 - the absence of a special economic zone in the region. 
The study priority was to assess the impact of institutional and sociocultural indicators on investment potential in the long term. For this reason, the rest of the indicators can be considered as benchmarks.

Like some studies, the authors used the volume of investment in fixed assets as a dependent variable of investment potential [6]. However, in our case, the volume of investment in fixed assets was taken not in aggregate value, but per capita.

Analysis of the data and statistics determined that the appropriate model for explanation is the fixed effects model.

From the possible fixed-effect models, the model with the first differences was chosen, since it allows to remove the effect of autocorrelation and is adequate from the point of view of the Ramsey test. For a proper specification of the model, some factors were removed from the final equation. The final variables included in the model are provided in Table 2.

Table 2. Final variables of the regression model.

\begin{tabular}{|c|c|c|}
\hline Parameter & Coefficient & Significance level \\
\hline const & -4630.91 & 0.1025 \\
\hline AvIncomes & 3.28675 & 0.0164 \\
\hline BAssets & 0.0124238 & 0.2762 \\
\hline DO & 34.0592 & 0.5439 \\
\hline Auto & 147.996 & 0.1902 \\
\hline Mortgage & 1.37274 & $5.88 \mathrm{e}-08$ \\
\hline Banksreg & 210.283 & 0.6798 \\
\hline Innov & -0.0263887 & 0.3507 \\
\hline Vobrab & 0.154124 & $1.91 \mathrm{e}-08$ \\
\hline Population & 485.362 & 0.0338 \\
\hline Fer & 457.764 & 0.8078 \\
\hline
\end{tabular}
form ${ }^{3}$ :

The final model based on the exclusion of insignificant variables has the following $\Delta$ Inv $=-2,29 \mathrm{e} 03+3,81 * \Delta$ AvIncomes $+1,55 * \Delta$ Mortgage $+0,150 * \Delta$ Vobrab $+547 * \Delta$ Population
$(2.19 \mathrm{e} 03)$
$(0.251)$
$(0.325)$

(226)

$\mathrm{n}=729, \mathrm{R}$-square $=0.312$

The only drawback of the model is the not very high R-square, however, according to the rest of the statistics, the model is proper, which may indicate its applicability to explain the influence of factors on the investment potential.

\section{Results and Conclusions}

The variables of interest were all sociocultural and institutional factors, except for the indicator of presence of special economic zones (OEZ), since dummy variables cannot be applied in the model with first differences.

Regarding the institutional and sociocultural factors, only the volume of mortgage loans (Mortgage) is significant - this may indicate that the cultural attribute of long-term orientation can increase investment per capita. In addition, the Mortgage indicator indirectly indicates the development of banking institutions, despitethe he weak significance of the indicator of the number of regional banks (Banksreg). This is due to the fact that resources for investment are offered not only by regional banks, the number of

${ }^{3}$ standard errors are specified in brackets 
which has been decreasing over the past 20 years, but also by branches of Moscow banks in the region, as well as by other financial institutions (venture capital and investment funds).

Socio-cultural indicators: the birth rate of organizations (DO), provision of the population with cars (Auto), as well as the institutional variable - the volume of innovative goods (Innov) are insignificant in the model. It can be assumed that they reflect the cultural characteristics of individualism; accordingly, the quality of the business environment and the institutions for protecting property rights are not so important for long-term investment processes in Russian regions.

The birth rate (Fer) was also focused on a long-term perspective and a long view, while its insignificance can be explained by the fact that the birth rate of the population, in contrast to the housing mortgage, is not tied to the territory.

Therefore, based on the results of the constructed regression model, it can be concluded that socio-cultural and institutional factors are insignificant for the investment potential of the region in the long term. The only significant factor that can affect the investment potential over a long period of time is the volume of housing mortgage loans. The affordability of housing for the population of the region can act as a factor of sustainability of the regional economy and be considered as a key benchmark of the regional investment strategy.

\section{References}

1. N. V. Zubarevich, Vliyanie pandemii na social'no-ekonomicheskoe razvitie i byudzhety regionov, Voprosy teoreticheskoj ekonomiki, 1 (10), 48-60 (2021). Access mode: DOI 10.24411/2587-7666-2021-10104

2. V. V. Klimanov, Byudzhetnaya decentralizaciya $v$ pandemiyu $i$ postpandemijnyh usloviyah, Zhurnal Novoj ekonomicheskoj associacii, 3 (51), 218-226 (2021). Access mode: DOI 10.31737/2221-2264-2021-51-3-11

3. E. A. Kolomak, Ekonomicheskie posledstviya COVID-19 dlya regionov Rossii, EKO, 12 (558), 143-153 (2020). Access mode: DOI 10.30680/ECO0131-7652-2020-12-143153

4. M. Yu. Malkina, Ustojchivost' regional'nyh ekonomik $i$ ee faktory, Nauchnye trudy Vol'nogo ekonomicheskogo obshchestva Rossii, 4, 397-403 (2021). Access mode: DOI 10.38197/2072-2060-2021-230-4-397-403

5. N. N. Miheeva, Ustojchivost' rossijskih regionov k ekonomicheskim shokam, Problemy prognozirovaniya, 1 (184), 106-118 (2021). Access mode: DOI 10.47711/0868-6351184-106-118

6. S. N. Rastvorceva, M. V. Snegur, A. S. Chencova, Modelirovanie investicionnoj privlekatel'nosti regiona, Nacional'nye interesy: prioritety i bezopasnost', 257, 39-44 (2014)

7. K. Bender, B. Rohregger, B. Kinuthia, G. Ikua, E. Schüring, C. Adamba, K. Alatinga, N. Pouw, Different pathways of social protection reforms: An analysis of long-term institutional change in Kenya, World Development, 137, 105210 (2021). Access mode: https://doi.org/10.1016/j.worlddev.2020.105210

8. R. Boucekkine, F. Prieur, C. Vasilakis, B. Zou, Stochastic petropolitics: The dynamics of institutions in resource-dependent economies, European Economic Review, 131, 103610 (2021). Access mode: https://doi.org/10.1016/j.euroecorev.2020.103610

9. P. Chang, Y. Chen, Informal institutions and comparative advantage of South-based MNEs: Theory and evidence, Journal of Development Economics, 148, 102566 (2021). Access mode: https://doi.org/10.1016/j.jdeveco.2020.102566 
10. V. Elango, K. Dhandapani, Does institutional industry context matter to performance? An extension of the institution-based view, Journal of Business Research, 115, 139-148 (2020). Access mode: https://doi.org/10.1016/j.jbusres.2020.04.037

11. A. Elizalde, On the economic effects of Indigenous institutions: Evidence from Mexico, Journal of Development Economics, 147, 102530 (2020). Access mode: https://doi.org/10.1016/j.jdeveco.2020.102530

12. T. Fu, Do economic institutions matter for trade liberalization? Evidence from China's Open Door Policy, Research in International Business and Finance, 55, 101330 (2021). Access mode: https://doi.org/10.1016/j.ribaf.2020.101330.

13. J. Heavilin, H. Songur, Institutional distance and Turkey's outward foreign direct investment, Research in International Business and Finance, 54, 101299 (2020). Access mode: https://doi.org/10.1016/j.ribaf.2020.101299.

14. E. Kolomak, Economic effects of pandemic-related restrictions in Russia and their spatial heterogeneity, R-Economy, 6 (3), 154-161(2020)

15. V. Nedić, D. Despotović, S. Cvetanović, T. Djukić, D. Petrović, Institutional reforms for economic growth in the Western Balkan countries, Journal of Policy Modeling, 42 (5), 933-952 (2020). Access mode: https://doi.org/10.1016/j.jpolmod.2020.04.002

16. F. Nyame-Asiamah, I. Oduro Amoako, J. Amankwah-Amoah, Y. Debrah, Diaspora entrepreneurs' push and pull institutional factors for investing in Africa: Insights from African returnees from the United Kingdom, Technological Forecasting and Social Change, 152, 119876 (2020). Access mode: https://doi.org/10.1016/j.techfore.2019.119876

17. A. Rodríguez-Pose, M. Zhang, The cost of weak institutions for innovation in China, Technological Forecasting and Social Change, 153, 119937 (2020). Access mode: https://doi.org/10.1016/j.techfore.2020.119937

18. L. Sanderink, N. Nasiritousi, How institutional interactions can strengthen effectiveness: The case of multi-stakeholder partnerships for renewable energy, Energy Policy, 141, 111447 (2020). Access mode: https://doi.org/10.1016/j.enpol.2020.111447

19. P. Veiga, P. Teixeira, R. Figueiredo, C. Fernandes, Entrepreneurship, innovation and competitiveness: A public institution love triangle, Socio-Economic Planning Sciences, 72, 100863 (2020). Access mode: https://doi.org/10.1016/j.seps.2020.100863

20. C. Wang, H. Chung, Business networking and innovation of Asian enterprises in Western countries: The moderation of institutional distance, Industrial Marketing Management, 88, 152-162 (2020). Access mode: https://doi.org/10.1016/j.indmarman.2020.05.002

21. D. Wang, W. Huang, Centrality-based measures of financial institutions' systemic importance: A tail dependence network view, Physica A: Statistical Mechanics and its Applications, 562, 125345 (2021). Access mode: https://doi.org/10.1016/j.physa.2020.125345

22. G. Winch, Maytorena-Sanchez E., Institutional projects and contradictory logics: Responding to complexity in institutional field change, International Journal of Project Management, $38 \quad$ (6), 368-378 (2020). Access mode: https://doi.org/10.1016/j.ijproman.2020.08.004 